Marco Schneider; Ricardo M. Pimenta:

\title{
Walter Benjamin's Concept of History and the plague of post-truth
}

\begin{abstract}
:
Tomas Aquinas defined truth as the correspondence between things and understanding. Castro Alves paints the horror of the slave nautical traffic. In his essay On the Concept of History, Walter Benjamin reminds us: "The tradition of the oppressed teaches us that the 'emergency situation' in which we live is the rule." This 'emergency situation' was Fascism. Albert Camus defended his romance La Peste against the accusation of Roland Barthes that is was "dehors de I'histoire", pointing out that it was not only about the recent historical phenomenon of Fascism, but also about the permanent risk of its rebirth. Agnes Heller associates faith with prejudice and alienation. The following article will explore the Thomist concept of truth, Benjamin's concept of history, Camus' allegory of the plague, Agnes Heller's notion of faith and Castro Alves' powerful denouncement of slave traffic, to better criticize the phenomenon of post-truth, a rebirth of fascist information practices.
\end{abstract}

\section{Agenda:}

Introduction

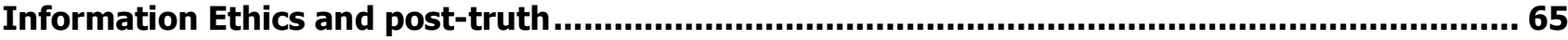

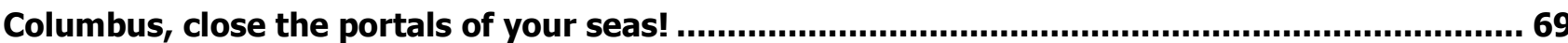

\section{Authors:}

\section{Prof. Dr. Marco Schneider:}

- Brazilian Institute of Information in Science and Technology (IBICT). Rua Lauro Müller, $455,4^{\text {th }}$ floor, Botafogo, Rio de Janeiro-RJ, 22290-160, Brazil; Fluminense Federal University (UFF). R. Prof. Lara Vilela, 126 - São Domingos, Niterói-RJ, 24210-590, Brazil.

- 淄 + 55-21-3873-9450, $\square$ marcoschneider@ibict.br

- http://buscatextual.cnpq.br/buscatextual/visualizacv.do?id=K4730044H1

- Relevant publications:

- A Dialética do Gosto: informação, música e política. Rio de Janeiro: Circuito/Faperj, 2015, 328 p.

- Gramsci, Golem, Google: a marxist dialog with Rafael Capurro's Intercucultural Information Ethics. In: Matthew Kelly; Jared Bielby. (Orgs.). Information Cultures in the Digital Age. A Festschrift in Honor of Rafael Capurro. 1aed.: Springer, 2016, p. 373-383.

\section{Prof. Dr. Ricardo M. Pimenta}

- Brazilian Institute of Information in Science and Technology (IBICT). Rua Lauro Müller, $455,4^{\text {th }}$ floor, Botafogo, Rio de Janeiro-RJ, 22290-160, Brazil

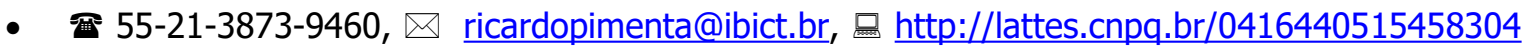

- Relevant publications: 
- PIMENTA, Ricardo M. Ciberespaço, internet e habitus: uma reflexão bourdieusiana sobre a era digital. In: Regina Maria Marteleto; Ricardo Medeiros Pimenta. (Org.). Pierre Bourdieu e a produção social da cultura, do conhecimento e da informação. 1ed.Rio de janeiro: Garamond, 2017, v. 1, p. 241-258.

- PIMENTA, Ricardo M. As rugosidades do Ciberespaço: um contributo teórico aos estudos dos web espaços informacionais. Informação \& Sociedade (UFPB. Online), v. 26, p. 77-90, 2016. Available in <http://www.ies.ufpb.br/ojs/index.php/ies/article/view/28116>. Access 16 out. 2017. 


\section{Introduction}

Columbus, close the portals of your seas!

(Castro Alves)

In the $13^{\text {th }}$ century, Tomas Aquinas defined truth as adequatio rei et intelectus, translated approximately as the correspondence between things and understanding, curiously similar to the positivistic notion of scientific knowledge.

The problem with the definition is not that it is wrong, but that it is not true enough, if we only keep in mind the linguistic turn in 20th century philosophy over the performative, expressive, constitutive relations between language and any conceivable understanding of reality. We know now that language is not only referential, nor a transparent instrument of communication; it structures our sense of reality, even our unconscious, if we agree with the French psychoanalyst Jacques Lacan. Besides, reality, whatever it is, is only thinkable and understandable through language.

Nevertheless, the recognition of the fact that language mediates any conceivable relation between things and understanding does not solve the problem of truth. So, as our aim is not to solve it, but to criticize the social phenomenon of post-truth, we will explore the hypothesis that the Thomist definition of truth, articulated with Benjamin's concept of history, Camus' allegory of the plague, Heller's notions of alienation and faith, and Castro Alves' powerful denouncing of the nautical slave market, might be heuristically useful.

Post-truth, as we shall demonstrate, is a sociotechnical actualization of traditional fascist information practices that takes place in cultural industry and the internet.

Approximately seven centuries after Thomas Aquinas, Walter Benjamin states, in his 1940 essay On the Concept of History.

"The tradition of the oppressed teaches us that the 'emergency situation' in which we live is the rule. We must arrive at a concept of history that corresponds to this. Then it will become clear that the task before us is the introduction of a real state of emergency; and our position in the struggle against Fascism will thereby improve. Not the least reason that the latter has a chance is that its opponents, in the name of progress, greet it as a historical norm. - The astonishment that the things we are experiencing in the $20^{\text {th }}$ century are 'still' possible is by no means philosophical. It is not the beginning of knowledge, unless it would be the knowledge that the conception of history on which it rests is untenable. "1

By '"emergency situation' in which we live", Benjamin was talking about Fascism. The mentioned "astonishment" came from a wrong positivist linear evolutionary concept of history, shared by social democrats, liberals and vulgar communists of his time (different from the philosophical astonishment that reveals new ways to understand old things). For this perspective, such a monstrosity like Fascism could not happen in the $20^{\text {th }}$ century, an age of Science, progress and reason. On the other hand, those seriously schooled in Marxist theory, as was the case with Benjamin, were not ingenuously astonished. From a Marxian perspective, Fascism was a somehow predictable extreme reaction of the ruling classes - allied with large sectors of the petite bourgeoisie,

\footnotetext{
${ }^{1}$ Benjamin, Walter: On the Concept of History. Available at: https://www.marxists.org/reference/archive/benjamin/1940/history.htm. Access on October 2017. All the quotations of this text in this paper come from this source. As there is no page numbers, and being easy to find the quoted texts by the Ctrl+F reseasrch tool, we will not repeat this reference.
} 
the lumpen proletariat and the most alienated sectors of the working class - against the growing of the organized working class movements amidst the imperialist crisis of the first half of the $20^{\text {th }}$ century. From this perspective, spanning the beginning of the 1920s until the end of the 1940s, Fascism grew as the institutionalized actualization of the plague of irrationality in intercourse with extreme oppression and brutality, an "emergency situation" about which "the tradition of the oppressed teaches us that [...] is the rule."

A decade and a half after Benjamin, the Algerian writer Albert Camus (who was the winner of the 1957 Nobel literature prize and member of the French resistance in the Second War) defended his romance, La Peste (1947), against the accusation of Roland Barthes, in a letter (1955) to him, positing that it was not "dehors de I'histoire". ${ }^{2}$ Camus answered that La Peste was not only about the recent historical phenomenon of Fascism, but about the permanent historical risk of its rebirth; that it should lead us to be aware. In this sense, La Peste reminds us that Fascism was not destroyed forever. As the bacillus of the Great Plague, it can be reborn, since its inner entropic potency has not ultimately been destroyed, if ever it could be, despite its apparent and provisory defeat in 1945.

In 1970, Agnes Heller associated faith with prejudice and alienation. For Heller, faith is the affection of prejudice, an expression of alienation, which "is always alienation in the face of something and, more precisely, in the face of the concrete possibilities of the generic development of humanity." $(2004$, p. 38)

In a vigorous and, as far as we know, original criticism of the capitalist system as a whole, she defines it as the most intense form of alienation in history, presenting the following arguments:

"There is alienation when there is an abyss between human-generic development and the possibilities of development of human individuals, between human-generic production and the conscious participation of the individual in this production. This abyss did not have the same depth in all ages or in all social strata; thus, for example, it closed almost completely in the epoch of the flourishing of the attic polis and of the Italian Renaissance; but in modern capitalism, it has gone deeper. (Heller, 2004, pp. 38-9)"

One of the most infamous expressions of this deepening of alienation, before Auschwitz, was the capitalist slave nautical traffic. In 1869, Castro Alves, a young Brazilian poet and abolitionist, published The Slave Ship three years after the first successful intercontinental transmission by submarine telegraph cables from Europe to the USA: "Glory to God in the highest; on Earth, peace and good will towards men".

Meanwhile, we can read in Castro Alves' poem ${ }^{3}$ :

\section{"Lord God of the unfortunate! Tell me Lord God! \\ If it is madness or truth \\ So much horror under the skies?!"}

We can incorporate here the horror under the seas: telegraph cables and all kinds of communication and informational advances achieved on the backs of the nautical traffic of black men. Even when cables and slaves were not transported by the same ships, they were by the same capitals or, at least, by kindred ones. These nightmare trade journeys also allowed the establishment of new forms and technological structures of

\footnotetext{
${ }^{2}$ See https://etlettera.wordpress.com/2015/01/15/1s-es-l-lettre-dalbert-camus-a-roland-barthes-sur-la-peste-janvier-1955.

${ }^{3}$ Disponível em: http://www.dacostaex.net/livros/NAVIO\%20NEGREIRO.pdf
} 
exploitation. Decades later, new cables spread all over the world, replacing the telegraph and establishing more perennially the informational and communicational infrastructure of what we now know as cyberspace.

Together with the emancipatory, democratic and deliberative possibilities present in the territory of cyberspace and the Internet, we must not ignore the fact that this whole "simulacrum", which certainly influences the social physical space, remains anchored by a system that is not virtual, but in fact very real. As discussed by Pimenta (2016), submarine cables and large servers continue to evidence an old form of socioeconomic domination and control. From the monopoly of the technology necessary for the production and circulation of material goods, to the monopoly of technology necessary for the production and circulation of information on a global scale, these things play a strong economic and ideological role in the global political economy of info-communications.

\section{Information Ethics and post-truth}

The following section addresses the phenomenon of post-truth from the above perspective. Our Marxian approach to Information Ethics connects it to Information Epistemology and to the political dimensions of Information.

First, we engage Epistemology in its broadest sense as that which aims to distinguish objective, realistic, rational knowledge from subjective, fictional, irrational opinions and beliefs. We note that, while subjective, fictional, irrational opinions and beliefs are also objective phenomena and contain their own inner rationality, their own particular truth, it is important to differentiate their narratives from scientific ones. The former are particulars. The later aim to be universal.

Second, we posit that truth (however defined), opinion and beliefs - whose constitutive intersubjective body is Information, the material of any performative language (i.e., potential or actual communication), in all kinds off records - are always, somehow, expressions of social power relations.

Our intent is not to claim that truth and science always side with each other and that opinion and belief are necessarily falsehoods. Epistemology positions truth in rationality, while information ethics and politics position truth in practical judgements about the relationship between moral values and consequences of information processes. The two are not always homologous.

The goal of this article is to establish a basis for distinguishing good knowledge from bad knowledge, good science from bad science and good opinion from bad opinion, where good is defined ethically, politically and epistemologically.

We can find good and bad knowledge in both science and opinion. Following Plato (see Menon, 1950), the difference between Episteme and doxa is not the distinction between truth and lie, but rather between a kind of knowledge that reflects self-critically with an aim towards establishing its own logical basis and another that does not. Science is founded on a rigorous commitment to the production of true knowledge through rational self-criticism and sound argumentation. There is, indeed, a scientific doxa, as Bourdieu demonstrated, and critical thoughts in popular culture, as Gramsci demonstrated, but the first is not good science, while the later is good opinion.

Epistemology deals with true and false knowledge; Politics deals with freedom and oppression; Information Epistemology and Information Politics are Information Ethics issues.

The most radical ideas of Enlightenment are Reason and Freedom. The concept of Reason, different from instrumental reason and from mere understanding, is necessarily universal, but not necessarily contradictory to particular forms of instrumental reason or understanding. Nevertheless, the historical efforts to reconcile the two have traditionally favoured totalitarian particulars masked as universals (false universals) or totalitarian assumed particulars against the concrete universal in its rational historical development, to put it in Hegelian 
terms. Christianism, Islamism, colonialism and historical communism, we say, are examples of the former; Fascism of the later. On the contrary, the idea of Communism, as the effectiveness of its concept, points towards a dynamic, never ended conciliation, among individuals, particulars and universals; to a rational common freedom. It does not mean homogeneity, but equality, an open state of no mutual oppression of the diversity, nor of oppression of false universals against particulars, nor of individuals or particulars against individuals or other particulars. It does not necessarily lead to universal love or fraternity, but to universal respect and dignity as inflexible categorical imperatives.

We must add that, as much as the definition of truth is not an easy one, so too is the definition of freedom not easily ascribed. We do not intend to solve either, but rather to present potentials for both in the dichotomy of lie and oppression, the unethical political and epistemological essences of Fascism. Fascism - more than any other known socio-system - admittedly construes falsehoods as truths, political and economic oppression as the right of the strongest, and the wealthier as the pure and superior race, all at the expense of the weak, the invalid, and the "inferior", and it does so apart from any rational grounding. Thus, Historical Fascism is an excellent example of what truth and freedom are not.

Goebbels' well-known statement, "Repeat a lie often enough and it becomes the truth", exposes the core of the information ethical, epistemological and political problem of Fascism. A lie that becomes truth in public opinion is an ideology. Ideology, in the pejorative sense of the word, is a false consciousness that rationalizes and legitimates human exploitation through generalizations, ignorance and lies. At its worst, it legitimizes genocide, the best-known example of this being Nazi Germany.

Despite the realization of Goebbels' maxim in Nazi Germany, it was not true that the Jews were the cause of communism and capitalism at the same time, or not, despite the existence of influent Jewish capitalists and communists. It was not true that there was a Jewish conspiracy to conquer the world. The Nazi's "final solution", besides being an ethical abomination, cannot realistically be taken seriously as a logical methodology, since, if successful, it would not have even superficially stopped capitalist exploitation nor the growth of communism. In fact, "national socialism" contributed to the transformation of communism into Stalinism, to the grow of western imperialism, to the emergence of the cold war, to nuclear proliferation, and to right wing Zionist justification of the oppression over the Palestinians. It was not at all true that the Nazis fought against capitalist exploitation, but to better position the German ruling class among the imperialist spoils of global economic, political and cultural control. Nevertheless, repeated lies and misinformation become so prevalent among the population, as ideology, as belief, as prejudice, as faith, that they become a material force in place of grounded theory; here noting Marx's statement on the Introduction of his Critic of Hegel's Philosophy of Right (2005, p. 151). Marx knew that the weapon of criticism required comprehension and adoption by the masses or it remains ineffective.

Following Burawoy (2010, p. 77), the problem with the notion of ideology as false consciousness, for Bourdieu, does not lie in the adjective "false", but in the idea of consciousness. The symbolic domination or violence operates unconsciously as beliefs that favour the reproduction of the same economic and symbolic domination that produces these beliefs.

For the Hungarian philosopher Agnes Heller, one can only understand prejudice via the nuances of everyday experience: momentary character of effects, ephemeral nature of motivations, rigidity of the way of life, thought fixed in empirical, ultra-generalizing experience. We come to ultra-generalizations by stereotypes. Ultrageneralizations can arise from both tradition and attitudes that oppose it. 
Another source of prejudice is conformism: "Every man needs [...] a certain amount of conformity. But this conformity becomes conformism when [...] the motives of conformity of daily life penetrate into the non-daily spheres of activity, especially in moral and political decisions [...]". (2004, p. 46) ${ }^{4}$

Turning to the question of the genesis of prejudice in provisional judgment, Heller argues: "Provisional judgments refuted by science and by a carefully analysed experience, but which remain unshaken against all arguments of reason, are the prejudices. [...] Hence, it was illusory that the Enlightenment had hoped to eliminate prejudice in the light of reason. Two different affections can connect us with an opinion, vision or conviction: faith and trust. Faith is the affection of prejudice. "(2004. p. 47)

At this point, Heller develops an important distinction between faith and trust, and prejudice is the differentiating element. She develops the analysis at three levels, the anthropological, the epistemological and the ethical, where the anthropological serves as the basic function of the others.

At the anthropological level, faith refers to individual particularity, and trust, to conscious individuality; in the epistemological, faith is knowledge that resists knowledge and experience, while trust is based on knowledge opened to change; on the ethical level, finally, the mark of faith is emotional intolerance; that of trust, the potential openness to tolerance.

Prejudice constitutes a system indispensable to social cohesion the more threatened it becomes:

"The system of prejudices is not essential to any [social] cohesion as such, but only to the threatened cohesion.

Most, but not all, prejudices are the products of the dominant classes [...] The foundation of this situation is evident: the ruling classes want to maintain the cohesion of a social structure that benefits them and mobilize in their favour even the men who represent diverse interests (and even, in some cases, the dominated and antagonistic classes). With the help of prejudices, they appeal to individual particularity, which - because of their conservatism, their complacency and their conformism, or also because of their immediate interests - is easy to mobilize against the interests of their own integration and against oriented praxis in the human-generic sense. [...] The cohesion of bourgeois society was, from the first moment, more unstable than that of classical antiquity or Feudalism. Therefore, the so-called group prejudices (national, racial, ethnic prejudices) only appear in the historical plane, in its proper sense, with bourgeois society.

The contempt for the 'other', the dislike of the different, is as old as humanity itself. Nevertheless, before bourgeois society, the mobilization of entire societies against other societies, through systems of prejudice, has never been a typical phenomenon. (Heller, 2004, pp. 54-5)"

On the other hand, the dialectical element present in Heller's thought keeps her analysis from stagnation, since, although she acknowledges the impossibility of a complete elimination of prejudices, "eliminating the organization of prejudices in a system" remains, in her view, possible:

"[...] prejudices could cease to exist if the peculiarity that functions with complete independence from the human-generic, the affection of faith, satisfying this particularity, disappears, and, on the other hand, all social integration, every group and every community that feel threatened in their cohesion.

We believe that such a disappearance is by no means utopian, since it appears with the idea of a society in which every man can become an individual, can configure the conduct of life by himself, and in which

${ }^{4}$ Quoted from the Brazilian edition. Translated to English by the authors. 


\begin{abstract}
particularity ceases to function, independently of the human-generic. In such a society, the false provisional judgments would not be suppressed, but adherence to them, dictated by faith, would be abolished, that is, their crystallization in prejudice would disappear. [...] But as the possibility of elevating oneself to the condition of the real individual is given only to each singular being (which in no way means that every single being becomes individual), it becomes evident that prejudices can not be totally eliminated from social development. But it is possible, in return, to eliminate the organization of systemic prejudices, their rigidity and - most importantly - the discrimination effected by prejudices. (Heller, 2004, pp. 58-9)"
\end{abstract}

The term post-truth was the Oxford Dictionary Word of the Year for 2016. Being thus timely, we propose a definition of post-truth as the Oxford Dictionary defines it: Post-truth is "an adjective defined as 'relating to or denoting circumstances in which objective facts are less influential in shaping public opinion than appeals to emotion and personal belief'." ${ }^{5}$ Post-truth also has a very important sociotechnical particularity, that being its far-reaching ability to influence action as broadcast and through mass niches and expedited in articulated performances of cultural industry, algorithms and robots.

While Cultural Industry can propagate equal "appeals to emotion and personal belief" at a large scale, algorithms and robots are able to reproduce the same appeals with precision, also in large scale, but for specific groups of customers. These devices identify and reinforce beliefs, opinions and tastes through ubiquitous digital surveillance processes, from Google searches, Amazon shops, and Facebook "likes", with the goal of gaining adhesion and increasing circularity among the internet's social networked users.

While the Thomist notion of truth defines it as the correspondence of things and understanding: Veritas est adaequatio rei et intellectus, post-truth is the correspondence of beliefs, prejudices, faith and understanding. In both cases, what mediates things, beliefs, prejudices, faith and understanding, is Information, the activation of language's potency towards enlightenment or mystification, freedom or oppression.

We do not advocate that the old Thomist notion of truth solves this fundamental philosophical question, only that we should consider it, since doing so can help contribute to a clarification of the contemporary information ethical problem of post-truth, as outlined below.

Thus, we propose to conceive truth once again as the correspondence of things to understanding, keeping in mind Hegel's (2010) distinction between understanding (more particular, superficial and fixed knowledge) and reason (deeper, dynamic and universal knowledge), and between existence (sometimes contingent) and reality / effectiveness (always necessary), in their historical developments. As such, truth becomes the fruit of a dynamic dialectical relation between reality and rational knowledge.

We also propose to articulate this notion of truth via the Marxian conception of historical dialectics between social being and social consciousness. For Marx, since the division of human societies into owners and not owners of the means of production (land, tools, machinery, technological infrastructures etc.), class struggle, or the struggle for or against freedom, became the leitmotiv of historical reality.

This reasoning leads us to Benjamin's concept of history. History is not an evolutionary determinism based on empty concepts of time. Rather, it is an explanatory non-fictional narrative; its focus are the events that disclose

${ }^{5}$ See https://en.oxforddictionaries.com/word-of-the-year/word-of-the-year-2016 
class struggle as the essential reality of social existence, with new and rich concepts of time, particularly in terms of "messianic" time of which we will return to shortly. ${ }^{6}$

In a digital age, data deluge traverses time. It is compressed between nuances of the present (as increasingly smaller, more fleeting) and future (as increasingly more urgent, more sudden). Time ceases to obtain any possibility of witnessed reflexivity, its passing oppressed by industrious trappings. It is against such a backdrop that the information of post-truth is produced. Post-truth 'information' becomes capital, its value exponentially controlled by those who hold and regulate it.

In this new information game, the manipulation of time also becomes a means of exploitation and the agent of propaganda and misinformation through the control of production and knowledge.

\section{Columbus, close the portals of your seas!}

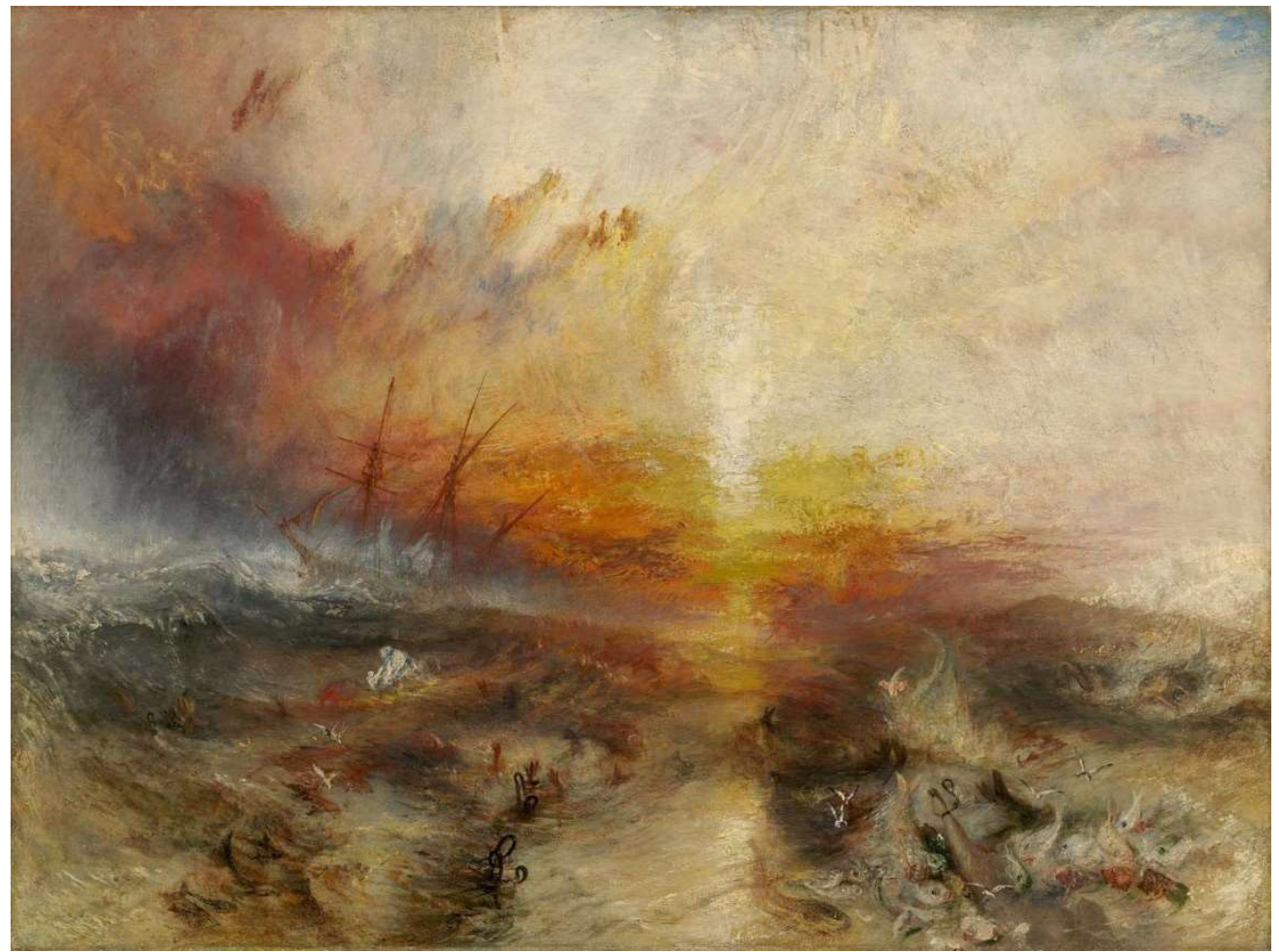

Turner. The Slave Ship ${ }^{7}$

\footnotetext{
${ }^{6}$ From the "Translator's Note" of the English version of Benjamin's On The Concept of History quoted here: "Jetztzeit was translated as 'here-and-now' ' in order to distinguish it from its polar opposite, the empty and homogenous time of positivism. Stillstellung was rendered as 'zero-hour', rather than the misleading 'standstill'; the verb 'stillstehen' means to come to a stop or standstill, but Stillstellung is Benjamin's own unique invention, which connotes an objective interruption of a mechanical process, rather like the dramatic pause at the end of an action-adventure movie, when the audience is waiting to find out if the time-bomb/missile/terrorist device was defused or not)." See https://www.marxists.org/reference/archive/benjamin/1940/history.htm.
}

7 Turner. The Slave Ship. https://en.wikipedia.org/wiki/The_Slave_Ship 
In 1869, the young Brazilian poet and abolitionist Castro Alves (1847-1871) published $O$ Navio Negreiro (The Slave Ship). The last sentence of the poem reads, "Columbus, close the portals of your seas!"

The contradictions and vices of the hopes of the colonial vision and the calamities that took place during the last three centuries in the name of universal freedom, justice, and reason are well documented. The slave market, consisting largely of black men, was probably the most abject example of such atrocities. Castro Alves' poem powerfully paints the apex of this market and its nautical slave traffic, now a metonymy of the worst of 19th century disputations, much in the same way that Auschwitz is a 20th century metonymy for the same.

Reproduced below are a few select verses from Castro Alves' poem. The selection demonstrates the poems' unique beauty and expressive power. Our intention is to both introduce the text to the readers of this paper and to highlight its allegorical connection to Benjamin, Camus and Heller. The events depicted in the poem were contemporary to a major information sociotechnical achievement, the submarine intercontinental telegraphic web - achieved on the backs of the above outlined nautical traffic.

In a paroxysm of alienation and brutality at the early stages of capitalism, both slaves and cables crossed the seas, carried by ships with similar purposes: to serve the owners of capital. Modern slavery served mainly North and South America's plantations, America being central for profitable commodities production and trade at the time, commodities that included silver, gold, cotton, tobacco, sugar, coffee, and rubber. As such, submarine communications cables were strategic for European and North American general trade, and like the cables first laid in the 1850s, information itself has likewise become capital for a modern digital era. Thus, the submarine telegraph cable together with the slave ship acts as an allegory for understanding how todays informational capital, in the form of data, has become one of the more penetrating methods of exploitation by modern corporations.

The Slave Ship ${ }^{8}$ begins with a scene of a swiftly sailing ship moving beneath the majesty of sky and ocean. The poet expresses his will to be an albatross, an "eagle of the seas", to closer study the sailing ship. However, as the scene closes in, the horror of the slave nautical traffic emerges:

"[...] what is it I see there...

What picture of bitterness it's funeral song!

What tetric figures!

What an infamous vile scene! My God! My God'. What horror:

IV

It was a dantesque dream... the deck

Great lights redenning its brilliance,

Bathing it in blood.

Clang of irons... snap of whip...

Legions of men black as the night

Horrible dancing...

Black women, holding to their breasts

Scrawny infants whose black mouths

Are watered by the blood of their mothers:

${ }^{8}$ Disponível em: http://www.dacostaex.net/livros/NAVIO\%20NEGREIRO.pdf 
Others, young, but nude and frightened,

In the whirlwind of specters drawn

From anxiety and vane resentment!

And the orchestra laughs, ironic, strident...

And from the fantastic circle a serpent

Spirals madly...

If the old man cringes, slips to the groused,

You bear shouts... the whip cracks.

And they High more and more..

Prisoned in the bars of a single jail

The famished multitude shudders,

And weeps and dances!

One is delirious from rabies, another is going road,

Another, bruttish from martyrdom

Sings, groans, and laughs!

Meantime the captain commands the maneuver

And after gazing at the sky which unfolds

So pure over the seas,

Cries out of the gloom of dense obscurity,

"Shake out the whip, mariners!

Make them dance, more!"

And the orchestra laughs ironic, strident

And from the fantastic circle a serpent

Spirals madly

Like a dantesque dream the shadows fly!

Shouts, ahs, curses, embodied prayers!

And Satan laughs!

The chorus follows:

"Lord God of the unfortunate!

Tell me Lord God!

If it is madness or truth

So much horror under the skies?!

Oh seas why do you not erase

With the sponge of the waves,

Your mantle, this blot?

Stars! Nights! Tempests!

Roll down from the immensity!

Sweep the seas, typhoon!"

The end of the slave trade in Brazil occurred beginning in 1850, with the promulgation of the Eusébio de Queirós Law. England pressed for its end, although it had profited from it between the seventeenth and nineteenth centuries. More than mere profits, slave nautical traffic was vital for the Industrial Revolution: "[...] at least 1.5 
million Africans have been transported from Africa to America by vessels leaving Liverpool. This contingent consists of more than $10 \%$ of the total number of slaves sold that are known."

This profit greatly contributed to the Industrial Revolution, which favoured the creation of the transcontinental submarine telegraph, the Internet's great-grandfather. The slave ship ironically sailed the seas while communication was simultaneously established in real time via the first form of transcontinental telegraphy:

"The invention of telegraphy by Samuel Morse in 1843 encouraged the idea of wiring cables across the Atlantic to utilize the new technology. North American Charles Field and Britain Charles Bright and brothers John and Jacob Brett founded a company to launch the first intercontinental telegraph submarine cable.

The following year, two ships, one British and one American, carried 2,500 nautical miles (4,630 km) of cable, departing from Ireland. The cable was broken as soon as they had been launched about $750 \mathrm{~km}$. New attempt was made in 1858 and new breakup occurred when only $250 \mathrm{~km}$ had been launched. Yet in 1858 there was a third attempt. This was successful; the ships left the middle of the Atlantic and reached ports on opposite sides without any occurrence of disruption. The message "Glory to God in the highest; on Earth, peace and good will towards men" was sent.

This success, however, was short-lived, because a few weeks after this pioneering success, the cable due to problems of the voltages used failed. Only eight years later, reliable operations were assured in this communication between North America and Europe. ${ }^{10}$

A few years following the advent of telegraphy, Castro Alves published The Slave Ship. Its final verses read:

"Green-gold pendant of my land,

That the breeze of Brazil caresses and unfurls

Standard that in the light of the sun encloses

Promises of divine hope. . .

You, who in the liberty after war,

Were hoisted by heroes on the lance,

Rather that you had been torn in battle

Than serve a people as a shroud! . . .

Atrocious fatality that overwhelms the mind

Extinguish this hour loathsome brig

The furrow that Columbus opened in the waves,

Like an iris in the depth of the seas!

But this is too much infamy!... From the ethereal region

Rise, heroes of the New World!

Andrada! ${ }^{11}$ Rip that pendant from the air!

Columbus! Close the portals of your seas!"

\footnotetext{
${ }^{9}$ Originally published in Portuguese. English translation by the authors. See: Hashizume, Maurício. Arquivo mostra como escravidão enriqueceu os ingleses.

${ }^{10}$ See: https://pt.wikipedia.org/wiki/Cabo_submarino.

11 José Bonifácio de Andrada e Silva (Santos, June 13, 1763 - Niterói, April 6, 1838) was a Brazilian naturalist, statesman, and poet. He is known by the epithet "Patriarch of Independence" for being a decisive person for the Independence of Brazil. See:

https://pt.wikipedia.org/wiki/Jos\%C3\%A9_Bonif\%C3\%A1cio_de_Andrada_e_Silva.
} 
Benjamin's notion of "messianic power" also demands, in a way, that Columbus close the portals of his seas. The refrain, "Rise, heroes of the New World!", though directed to the humanity of Castro Alves' time, still rings true in Benjamin's and in our own age as an eschatological verdict to end the age of calamity. While such a verdict transcends all ages, for Benjamin, it is communism that fulfils the prophetic age, thus correlating the communist project to what he calls "messianic force". This is not a rehearsed idealist theological utopia, but a re-reading of Jewish messianism in its most inspiring materialistic terms, as a necessary expression of human potential to overcome oppression once and for all. It is an expression of human creative and combative need for freedom, solidarity and sensuality.

In Benjamin's words:

"The past carries a secret index with it, by which it is referred to its resurrection. Are we not touched by the same breath of air which was among that which came before? Is there not an echo of those who have been silenced in the voices to which we lend our ears today? Have not the women, who we court, sisters who they do not recognize anymore? If so, then there is a secret protocol [Verabredung: also appointment] between the generations of the past and that of our own. For we have been expected upon this earth. For it has been given us to know, just like every generation before us, a weak messianic power, on which the past has a claim. This claim is not to be settled lightly. The historical materialist knows why."

The historical materialist attests as follows:

"The class struggle, which always remains in view for a historian schooled in Marx, is a struggle for the rough and material things, without which there is nothing fine and spiritual. Nevertheless these latter are present in the class struggle as something other than mere booty, which falls to the victor. They are present as confidence, as courage, as humour, as cunning, as steadfastness in this struggle, and they reach far back into the mists of time. They will, ever and anon, call every victory, which has ever been won by the rulers into question. Just as flowers turn their heads towards the sun, so too does that which has been turn, by virtue of a secret kind of heliotropism, towards the sun which is dawning in the sky of history. To this most inconspicuous of all transformations the historical materialist must pay heed."

Thus, the horizon of the communist revolution as "the sun which is dawning in the sky of history", was in Benjamin's time a response to a state of emergency whose task was to introduce a struggle against Fascism, as noted above.

Communism, from a messianic stance, promises an end to reification, the end of the naturalization of the most violent social process, the transformation of subjects into objects, of humans into things. In other words, it is an end to the matrix of the violence of capitalism, from which all other forms of violence emerge.

Such a concept, even before Marx and Lukács, find its roots, among other places, in Kant (2002). Kant stated that we must categorically forbid the reduction of subjects to objects as it blocks the subject's inner powers for freedom, i.e., for achieving the good will to act according to reason.

Hegel was the first to disclose the necessary socio-historical aspects of this problem and its possible solution, asserting that this good will, or, in his terms, the free will that wants the free will, can be effective only through stated laws and institutions that allows and pushes its flourishment. 
Marx always insisted on the necessity of the practical actualization of these philosophical achievements, emphasizing often the central role of the popularization of the combative and emancipatory theory, the popularization of the best information. ${ }^{12}$

The necessary criticism against the contradictions between the west's "grand narratives" - like enlightenment in general or even Marxism - and the historical traumatic events that vindicated them as theoretical sources, shouldn't lead us to abandon what is still fair and true in western universal hopes for freedom, justice, and reason. Nevertheless, the greatest part of the contemporary intelligentsia does not seem committed such a perspective. On this point, we are shamelessly weak, theoretically and practically, in comparison with the great critical thinkers and strategists of modernity, from Machiavelli to Lenin and Gramsci.

As such, we must remember again that Marx' 11th Thesis on Feuerbach was not at all a refusal of philosophy, but a necessary unfolding of some of its best ethical achievements. ${ }^{13}$ For Marx, after Kant and Hegel, there was nothing more to say about Ethics, in explicit and abstract universal ethical terms. Perhaps for him, it was enough to demonstrate that humans are potentially rational, i.e., can think and behave not only as egoist beasts, but also as socio-historical reasonable beasts. This means, we could and should guide our praxis, or at least the praxis of the majority towards less irresponsible, reckless and injudicious forms of social organization, where the majority would no longer be reduced to objects of a few, nor each of us to a barrier to the other's freedom. On the contrary, each of us must become the condition of other individual's freedom and self-flourishment (Marx; Engels, 2000).

\section{Final Remarks}

All cultural and historical worldviews, established within limited horizons, enact a drama of good and evil, of truth and lies, and of freedom and oppression, acting out the dialectical complexities of their times. The Marxian historical approach allows us to see, or at least to glimpse the whole with a larger perspective. Contemporary culture is unable to overcome capitalist entropic developments without first moving beyond post-modern relativism and its negation of "grands narratives". The necessary criticism over traditional "grand narratives" should not lend towards their complete rejection. On the contrary, perhaps we need, more than ever, new emancipatory and convincing "grands narratives". We should enrich them with all kinds of particular cultural mediations and singular experiences, but we must articulate these singular experiences and particular mediations in new emancipatory - carefully and effectively developed - universal programs.

We've defined information in this article as activated language, as the actualization of the potency of language, in oral discourses, written texts, movies, digital memes, and so on. Reality is a presupposition of the referential function of language and information, being grounded neither on prejudices nor beliefs, but rather rationally and empirically. Language is both a consequence of and a vehicle for our feelings and thoughts, enabling relation to the world; through information, it is also performative. Language is a human socialcreation. Where the social world is tensioned by class struggle, language and information allow for both an expression of this struggle and for weapons amidst it.

\footnotetext{
12 From the Information Ethics field, we can relate this idea at least to five Information Science current issues: information literacy, scientific communication, digital divide, knowledge organization, information regimes.

${ }^{13}$ See Schneider, 2015, p. 216.
} 
The philosophy of subject, from Descartes' cogito to Kant, replaced the traditional metaphysical ontological question about what is real with an epistemological problem about what can be known and became hegemonic in academic philosophy according to Ilyenkov (1977). We propose here a return to the former question about what reality is, without a pretension to solve it, and to the metaphysical notion of truth as adequatio. Not all narratives are equally true; some are extremely and deliberately false. Information modes - production, records, circulation, access, retrieval, organization, use etc. - are powerful social forces. Its devices and even its popular uses are controlled. Ignorance of these facts allows for a complacency that in turn permits a rebirth of fascism in old broadcast and new digital media post-truth forms.

This rebirth of fascism poses new challenges from an information ethics perspective. The bacillus of the fascist plague is growing, even in the most unexpected corners of "civilization". ${ }^{14}$ Through digital means, falsehoods are forged into belief systems, gradually increasing the entropic capitalist reification processes. From the universal growing of the unequal distribution of wealth to Trump's marketing election strategies to the 2016 soft "coup d'État" in Brazil, governments are abolishing the hard-won social rights built up over the last several decades, and in doing so, they are reinforcing racism and sexism and abolishing workers' rights.

Contemporary culture is defined by hedonistic nihilism, masked by ubiquitous sub-cultural dramas and Facebook driven narcissism. The potential and possibly imminent destruction of the future is commodified as sensationalism and spectacle via Youtube and dystopic Hollywood movies about war, environmental devastation, zombie apocalypse and plague. The lack of a rational and forward thinking hope-based realism negates the possibility of any genuine strategy towards a common and positive future for human beings and the planet. A new focus on praxis is required. A post-truth culture based on the repetition of lies - bad information, dangerous beliefs and a system wide ignorance of even the most fundamental and well established references - had gone too far.

The nautical slave traffic and Auschwitz were poisonous interlopers that deprived the vision of the Enlightenment, taking away from the republican humanist imperatives of liberté, egalité, and fraternité the necessary radical transformations of the bourgeois ownership regime, indispensable to ensuring universal good. Such chaotic developments make the dialectical contradictions between the singular (individual), the particular (social classes and other social groups, as religion or Nation) and the universal (humanity) interests increasingly entropic. Only the idea of communism, as the effectiveness of its concept, points to the overcoming of this contradiction.

An application of information ethics to contemporary class struggles finds its actualization of Benjamin's messianic force against axiological neutrality and the empty time of positivism, embodied in Castro Alves' claim, "Columbus, close the portals of your seas!", as a reprimand against not the entirety of western thought, but specifically imperialism, fascism, neoliberalism, and post-truth.

\footnotetext{
${ }^{14}$ See "German police stand by as neo-Nazis give Hitler salute at 'rock against foreigners' concert. Available at:
} http://www.wsws.org/en/articles/2017/07/20/germ-j20.html. 


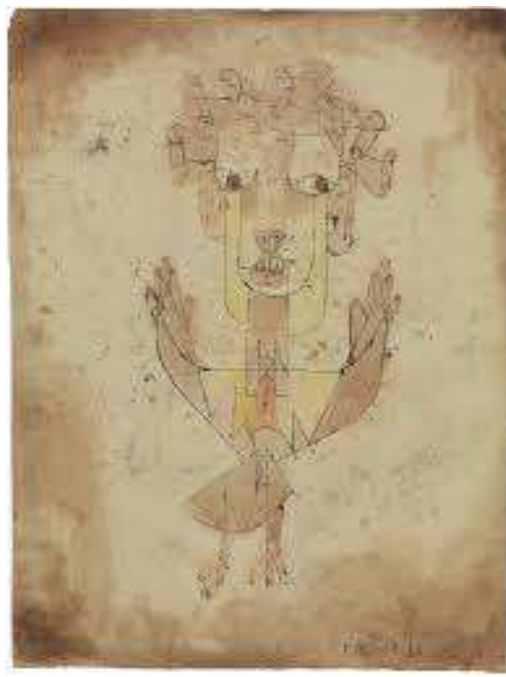

Paul Klee: Angelus Novus ${ }^{15}$

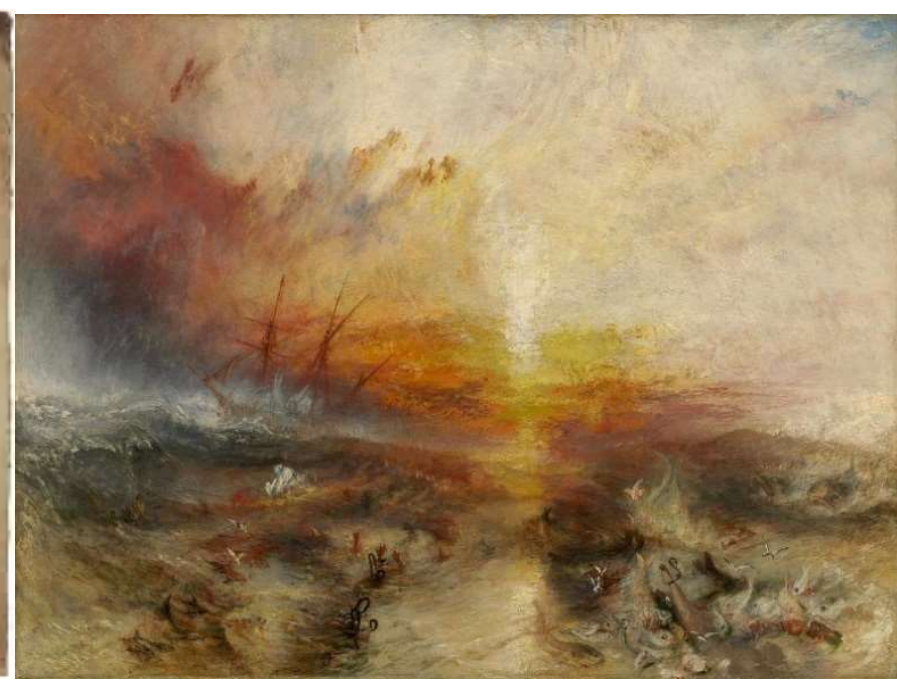

Turner: The Slave Sheep

\section{References}

Alves, Castro. The Slave Ship. http://www.dacostaex.net/livros/NAVIO\%20NEGREIRO.pdf, Access on October 2017.

Benjamin, Walter: On the Concept of History. Available at: https://www.marxists.org/reference/archive/benjamin/1940/history.htm. Access on October 2017.

Burawoy, Michael. O Marxismo encontra Bourdieu. Campinas, SP: Editora Unicamp, 2010, 183 p.

Camus, Albert. Lettre à Roland Barthes. https://etlettera.wordpress.com/2015/01/15/1s-es-l-lettre-dalbertcamus-a-roland-barthes-sur-la-peste-janvier-1955. Accessed at October 2017.

Camus, Albert. La Peste. Paris: Gallimard, 1947.

Hashizume, Maurício. Arquivo mostra como escravidão enriqueceu os ingleses. Repórter Brasil. Opera Mundi. Available at:

http://operamundi.uol.com.br/conteudo/noticias/27477/arquivo+mostra+como+escravidao+enriqueceut os+ingleses.shtm/\#. Accessed on October 2017.

Hegel, G.W.F. Filosofia do Direito. Prefácio. São Leopoldo/RS: Unisinos, 2010.

Heller, Agnes. O Cotidiano e a História. São Paulo: Paz e Terra, 2004.

Ilyenkov, Evald (1977). Dialectical Logic. Available at:

https://www.marxists.org/archive/ilyenkov/works/essays/index.htm. Accessed on October 2017.

Kant, Immanuel. Fundamentação da Metafísica dos Costumes e outros escritos. São Paulo: Martin Claret, 2002.

${ }^{15}$ Paul Klee. Angelus Novus. https://encrypted-

tbn0.qstatic.com/images?q=tbn:ANd9GcS9qm1 Rew0NePnBRvnbXDNuygS3Hd4EdDyoIqEFKMjgqVndCyJF. 
Klee, Paul. Angelus Novus. Available at: https://encryptedtbno.gstatic.com/images?q=tbn:ANd9GCS9qm1RewONePnBRvnbXDNuygS3Hd4EdDyoIqEFKMjgqVndCyJF. Accessed at October 2017.

Marx, Karl. Crítica da filosofia do direito de Hegel. Introdução. São Paulo: Boitempo, 2005.

Marx, Karl; Engels, Friedrich (2000). The Manifesto of the Comunist Party. Availale at: https://www.marxists.org/archive/marx/works/1848/communist-manifesto/. Acessed on October 2017.

Pimenta, Ricardo M. As rugosidades do ciberespaço: um contributo teórico aos estudos dos web espaços informacionais. Informação \& Sociedade: Estudos, João Pessoa, v.26, n.2, p. 77-90, maio/ago. 2016. Disponível em: http://www.ies. ufpb.br/ojs2/index.php/ies/article/view/28116/16202. Acesso em 11 out. 2016.

Platão. Diálogos: Menon-Banquete-Fedro. 2a.Rio de Janeiro: Globo, 1950.

Schneider, Marco. A Dialética do Gosto: informação, música e política. Rio de Janeiro: Circuito / Faperj, 2015. Turner, J.M.W. The Slave Ship. https://en.wikipedia.org/wiki/The Slave Ship. Accessed at October 2017. Vandreier, Christoph. German police stand by as neo-Nazis give Hitler salute at "rock against foreigners" concert. Worls Socialist Web Site, 20 July 2017. Available at: http://Www.wsws.org/en/articles/2017/07/20/germ-j20.html. Access on October 2017.

Wikipedia. Cabo Submarino. Available at: https://pt.wikipedia.org/wiki/Cabo submarino. Access on October 2017. 